\title{
VERSITA
}

\section{ABANDONMENT OF AGRICULTURAL LAND IN CENTRAL POLAND AND ITS ECOLOGICAL ROLE}

\author{
ANNA MAJCHROWSKA \\ University of Łódź, Faculty of Geographical Sciences, Department of Physical Geography, Narutowicza 88, 90-139 \\ Łódź, Poland; e-mail: majchrow@uni.lodz.pl
}

\begin{abstract}
Majchrowska A.: Abandonment of agricultural land in central Poland and its ecological role. Ekológia (Bratislava), Vol. 32, No. 3, p. 320-327, 2013.

The intent of this paper is to give an overview of the ongoing study of farmland abandonment in central Poland. The goal of this project, initiated in 2011, is to provide field-verified information: 1. What is the spatial distribution of abandoned agricultural land in central Poland? How is it related to biophysical features of the study area?

2. What are botanical characteristics of spontaneous vegetation succession in the abandoned agricultural lands? What are their environmental determinants?

3. How do the abandoned lands correspond to existing protected areas? How could they be used to strengthen the ecological landscape structure of central Poland?

The paper summarises the general study approach, discusses some methodological difficulties, presents preliminary findings and formulates the expected results.

Key words: agricultural abandonment, land use transitions, vegetation succession, rural landscape, landscape management.
\end{abstract}

\section{Introduction}

Farmland abandonment, i.e. the complete withdrawal of agricultural management so that spontaneous vegetation succession is able to progress, is a significant process in rural landscape throughout Europe (Strijker, 2005; Pointereau et al., 2008; Keenleyside, Tucker, 2010).

In Poland, due to the political and economic transformation, there was an immense increase in the area of abandoned farmland and fallow land from $1.1 \%$ of agricultural land in 1990 to $13.6 \%$ (17.6\% of arable land) in 2002 (GUS, 2004). Since then a decrease in abandonment has been observed in reaction to the introduction of the Common Agricultural Policy payments and the cross-compliance standards. In 2010, 5.8\% of agricultural area was not maintained in a good agricultural condition (GUS, 2011), which may be an approximation of the area of abandoned farmland (Table 1).

Farmland abandonment is a complex phenomenon, with a variety of causes and effects (Rey Benayas et al., 2007). It brings about an economic, environmental, social or/and cultural consequences, and therefore is growing in importance in various domains of policy, practice and research. 
T a b l e 1. The area of abandoned farmland in Poland (GUS, 2004; Harasimiuk, 2008; GUS, 2011).

\begin{tabular}{|c|c|c|}
\hline & \multicolumn{2}{|c|}{ Abandoned farmland area } \\
\hline Year & Million ha & \% of farmland \\
\hline 1990 & 0.16 & 1.1 \\
\hline 2000 & 1.67 & 9.2 \\
\hline 2002 & 2.30 & 13.6 \\
\hline 2005 & 1.03 & 7.9 \\
\hline 2006 & 0.98 & 7.5 \\
\hline 2010 & 0.89 & 5.8 \\
\hline
\end{tabular}

As explained by Höchtl et al. (2005), Rey Benayas et al. (2007) and Poláková et al. (2011), abandonment has a wide range of environmental implications, both negative and positive. Depending on diverse local and landscape factors (e.g. abiotic site conditions, biodiversity importance of the existing habitat, landscape fragmentation), the abandonment may decrease as well as increase landscape heterogeneity and species richness. Negative consequences include the following: (i) spread of undesirable invasive species, (ii) risk of fires (e.g. in the Mediterranean region), (iii) loss of traditional rural landscapes and (vi) loss of aesthetic values of landscape. The main advantages associated with farmland abandonment are (i) decrease in pollution by agricultural chemicals, (ii) improved water quality and hydrological regulation, (iii) recovery of soils and erosion mitigation, (iv) increase of carbon sequestration, (v) creation of new wildlife habitats, (vi) enhancement of ecological connectivity in fragmented landscape and (vii) improvement of ecological functioning within neighbouring protected areas.

Given the various implications of rural abandonment, we have begun a research project with the overarching goal to recognise ecological potentials for the abandoned farmland in central Poland. Specifically, we would like to provide field-verified information to help answer the following questions:

1. What is the spatial pattern of abandoned agricultural land in central Poland? How is it related to biophysical features of the study area?

2. What are the botanical characteristics of spontaneous vegetation succession in abandoned agricultural lands? What are their environmental determinants?

3. How do the abandoned lands spatially correspond to existing protected areas, in particular to landscape parks?

4. Can the abandoned lands be used to enhance the ecological landscape structure of the central Poland and supplement the existing network of protected areas?

Insights from the study could support the management of abandoned farmland for the benefit of landscape conservation and planning. They could help in the preparation of regional protection plans of landscape parks.

The aim of this paper is to give an overview of the ongoing research project on farmland abandonment launched in central Poland in 2011. In the following pages, it will describe the general study approach, some methodological difficulties, the preliminary findings and expected results. 


\section{Study area}

The study region in central Poland approximates the Łódź Province that has an area of $18220 \mathrm{~km}^{2}$ and ca. $2.53 \mathrm{mil}-$ lion inhabitants, with urban dwellers accounting for 64\% of the total. Łódź, with ca. 737000 inhabitants, is its main city (GUS, 2011a).

Central Poland is a flat and undulating glacial plain consisting of Quaternary till and fluvioglacial sands, with eolian deposits in places and Mesozoic rocks outcropping in the south. The altitude varies between $120 \mathrm{~m}$ and 250 $\mathrm{m}$. The area is a water divide, and it therefore lacks large streams. The major rivers, the Warta and the Pilica, flow on the periphery of the province.

Agricultural land accounts for about $71 \%$, forest $21 \%$, and the built-up area 5\% of the region (US w Łodzi, 2012)

In the project, we concentrated our efforts on seven landscape parks in the Łódź Province, together with 10 $\mathrm{km}$ wide buffer zones around the parks (Fig. 1). Landscape parks (or regional parks) are extensive tracts of country protected by law because of their environmental, historical, cultural and aesthetic values. Settlement, farmland and woodland uses and other commercial activities may be continued after the area is designated as a park.

The total investigated area is $8423 \mathrm{~km}^{2}$, and includes ca. $1218 \mathrm{~km}^{2}$ of the landscape parks and $7205 \mathrm{~km}^{2}$ of their buffer zones.

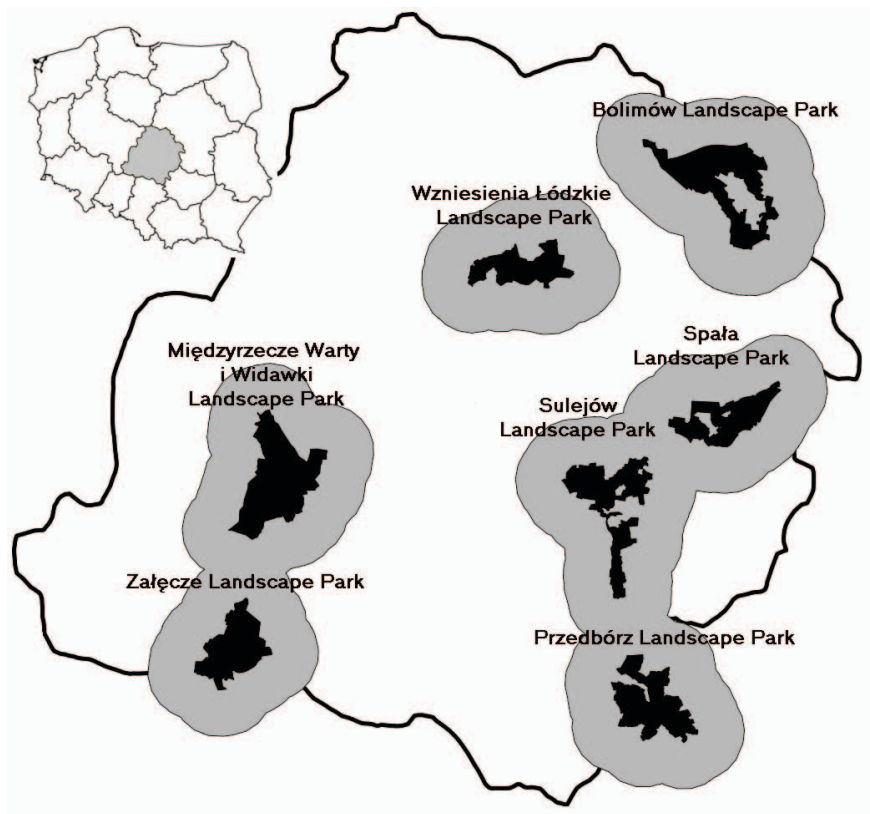

Fig. 1. The study area: Łódź Province and seven landscape parks with $10 \mathrm{~km}$ wide buffers.

\section{Study plan}

A detailed list of the study tasks includes the following:

1. To define the process of farmland abandonment and discriminative features of abandoned farmland.

2. To detect the location and assess the intensity of recent farmland abandonment within landscape parks and their $10 \mathrm{~km}$ wide buffer zones by visual interpretation of orthophotos.

3. To verify in field the results of visual interpretation of orthophotos.

4. To select detailed study sites with high concentration of abandoned farmland (2 sites per landscape park have 
been chosen in the buffer zones, all together 13 sites, as one of them is located in a common part of the buffer of two parks).

5. To carry out investigations of the 13 detailed study sites. The detailed investigations within the sites involve:

- $\quad$ mapping land use and cover;

- describing abiotic environmental and site conditions based on soil analysis, thematic maps and scientific literature;

- collecting floral data for the purposes of vegetation classification and description;

- collecting mycological data;

- $\quad$ establishing photo points to allow for ongoing monitoring and future comparisons;

- $\quad$ carrying out analysis of the data collected in field;

- examining vegetation-environmental relationship.

6. To explore spatial patterns of the abandonment process in the study area.

7. To assess suitability of the abandoned lands to strengthen the ecological landscape structure and supplement the existing network of protected areas.

\section{Definition of abandoned farmland}

The multitude of definitions of agricultural abandonment and difficulties in identification of abandoned farmland are thoroughly reviewed by Pointereau et al. (2008) (Table 2).

In our study, we have defined farmland abandonment as a cessation of farming activity on a given surface of land. Subsequent transformation of the land into tree plantation or artificial surface is not considered farmland abandonment, but just an agricultural land-use change. The farmland is referred to as abandoned if spontaneous vegetation may develop through succession into tall herbs, bushes and, finally, forest.

The definition of agricultural abandonment we have adopted represents landscape ecological approach (Pointereau et al., 2008) (Table 2), and is based on the description of vegetation cover.

\section{Identification of abandoned farmland}

The identification of abandoned land was based on visual interpretation of orthophotographs (orthophotos from 2009 viewable via Web Mapping Service hosted on Geoportal - www.geoportal.gov.pl) in square plots 500x500 m large. All together we have examined 33692 plots.

The estimate of abandoned farmland is difficult because its boundaries are not clear and there are similarities of vegetation cover between different land uses, as for example in cases of rough grasslands and ca. 5-year-old abandoned field (Faliński, 1986).

We were looking for lands that (i) had woody or mixed grass-woody growth as a result of natural succession, (ii) had been previously used for agriculture, (iii) were not used for agriculture any longer, (iv) were neither artificially afforested nor taken up by urbanisation or peri-urbanisation processes.

During the identification of abandoned farmland we have encountered several vaguenesses. Firstly, tree plantations on farmland could not be completely separated on orthophotos and are partly included as farmland abandonment. Secondly, non-utilised farmland that is waiting, in some cases several years, for allocation to housing purposes cannot be wholly excluded. Conversely, the so-called semi-abandonment or hidden abandonment (DLG, 2005), with a minimum level of management, which is necessary to claim the CAP payments or just to keep the area clear of woody growth so that it would be available for future use, is not counted.

We have quantified abandoned farmland in percentages of the plot area covered by spontaneous vegetation succession and assigned each plot to one of five classes of farmland abandonment:

- Class 0 (FLA0): no farmland abandonment

- Class 1 (FLA1): low level of farmland abandonment (up to 25\%)

- Class 2 (FLA2): medium level of farmland abandonment (25-50\%)

- Class 3 (FLA3): high level of farmland abandonment (50-75\%)

- Class 4 (FLA4): very high level of farmland abandonment (75-100\%).

Obtaining the data on geographical location and intensity of farmland abandonment by visual interpretation of orthophotos was a tedious and time-consuming task, but European databases such as the Corine Land Cover (CLC) or Farm Structure Survey (FSS) statistics were not suitable for our purpose. The CLC data are too coarse and 
underestimate land cover classes that tend to appear in small patches (Keenleyside \& Tucker 2010). We plan to use the CLC 2006 database as auxiliary data to separate forests and artificial areas in the study area.

T a b l e 2. The various definitions of farmland abandonment (Pointereau et al., 2008).

\begin{tabular}{|c|c|c|c|}
\hline Definition approach & Definition & Strengths & Weaknesses \\
\hline \multirow[t]{2}{*}{ Administrative } & $\begin{array}{l}\text { Farmland is abandoned if } \\
\text { left unmanaged for more } \\
\text { than } 5 \text { years }\end{array}$ & $\begin{array}{l}\text { Easiness to quantify with } \\
\text { investigation or declara- } \\
\text { tion. } \\
\text { Clear definition }\end{array}$ & $\begin{array}{l}\text { Only agricultural land } \\
\text { declared by farmers. }\end{array}$ \\
\hline & $\begin{array}{l}\text { Land which has not been } \\
\text { used for agricultural pro- } \\
\text { duction for } 2 \text { years. }\end{array}$ & Idem & Idem \\
\hline Economic & $\begin{array}{l}\text { The land is considered } \\
\text { abandoned when it is no } \\
\text { longer used as an eco- } \\
\text { nomic resource. }\end{array}$ & $\begin{array}{l}\text { Can be captured by the } \\
\text { price of the abandoned } \\
\text { land compared to the av- } \\
\text { erage price of agricultural } \\
\text { land. The farmer's price } \\
\text { should be lower. }\end{array}$ & $\begin{array}{l}\text { A land does not just have } \\
\text { an economic function. } \\
\text { Farming is only seen as a } \\
\text { sector that must maximise } \\
\text { profits. }\end{array}$ \\
\hline Social & $\begin{array}{l}\text { Land abandonment } \\
\text { following social and } \\
\text { structural changes. Gener- } \\
\text { ally people do not make } \\
\text { difference between fallow } \\
\text { land and non-utilised } \\
\text { farmland }\end{array}$ & $\begin{array}{l}\text { It takes into account the } \\
\text { causes of farmland aban- } \\
\text { donment: farmer's age, } \\
\text { farm size, etc. }\end{array}$ & $\begin{array}{l}\text { Can be too restrictive for } \\
\text { certain cases. }\end{array}$ \\
\hline $\begin{array}{l}\text { Landscape } \\
\text { Ecological }\end{array}$ & $\begin{array}{l}\text { Based on the description } \\
\text { of the vegetal cover: per- } \\
\text { centage of scrubs, bushes } \\
\text { or trees. }\end{array}$ & $\begin{array}{l}\text { Easiness to quantify } \\
\text { with satellite images or } \\
\text { surveyors. }\end{array}$ & $\begin{array}{l}\text { It is too restrictive. The } \\
\text { same vegetation state } \\
\text { can result from various } \\
\text { uses (e.g. grazing, nature } \\
\text { conservation) }\end{array}$ \\
\hline Agronomic & $\begin{array}{l}\text { Land where farming has } \\
\text { ceased and land which has } \\
\text { been under-exploited. }\end{array}$ & $\begin{array}{l}\text { There is an active process } \\
\text { with a central point, which } \\
\text { is farming. }\end{array}$ & $\begin{array}{l}\text { There are many states of } \\
\text { under-exploited land that } \\
\text { are not easy to differenti- } \\
\text { ate. }\end{array}$ \\
\hline
\end{tabular}

\section{Preliminary findings}

The map of farmland abandonment in the Wzniesienia Łódzkie Landscape Park and Bolimów Landscape Park and their $10 \mathrm{~km}$ buffer zones (Fig. 2) presents a diversified picture of the abandonment geographical distribution and intensity. Farmland abandonment is generally widespread in those regions as it occurs respectively in $52.4 \%$ and $43.7 \%$ of square plots within their areas (The FLA0 class in the map includes not only agricultural land with no abandonment but also forests and artificial surfaces).

With respect to the Wzniesienia Łódzkie Landscape Park, the share of the abandoned farmland is the lowest in its buffer zone (Table 3), which results from large areas of artificial surfaces of the Łódź agglomeration, located in the south-west. Low intensity of the abandonment in the north-east coincides mainly with agricultural areas. Inside the park, an open 
landscape prevails. The core area contains ca. 33\% of forest, which approximates the FLA0 class area in the park (Park Krajobrazowy Wzniesień Łódzkich, 2003). A large share of the core area has been assigned to the FLA1 class (Table 3), which suggests a mosaic-like rural Landscape pattern. Abandonment rates are the highest along the border of the park (500'500 m plots intersected by the border line), where $13 \%$ of the area is dominated by abandonment (FLA3 \& FLA4).

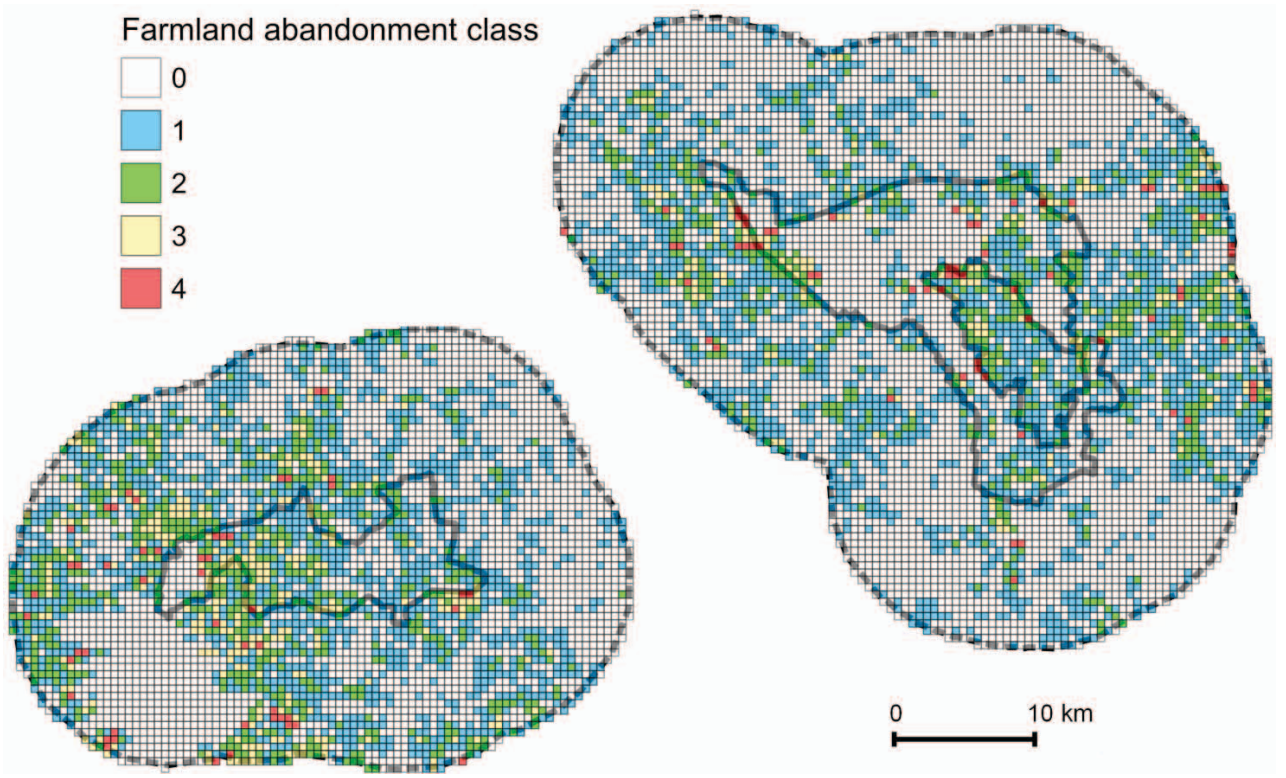

Fig. 2. The estimate of intensity of farmland abandonment in the Bolimów Landscape Park and Wzniesienia Łódzkie Landscape Park and their buffer zones.

The lowest abandonment rates occur in the core area of the Bolimów Landscape Park, which is the result of its vast forest cover. Similar to the previous case, the park border has the highest rates of abandonment (Table 3). Within the buffer zone of the Bolimów Landscape Park, agriculture, mainly fruit growing in the south-east, takes an important role, and there-

$\mathrm{T}$ a b l e 3. Per cent of the area of farmland abandonment classes in the buffer, border and core of the Bolimów Landscape Park and Wzniesienia Łódzkie Landscape Park.

\begin{tabular}{|l|l|l|l|l|l|l|}
\hline \multirow{2}{*}{ FLA class } & \multicolumn{2}{|c|}{ Wzniesienia Lódzkie Landscape Park (\%) } & \multicolumn{3}{c|}{ Bolimów Landscape Park (\%) } \\
\cline { 2 - 7 } & Buffer & Border & Core & Buffer & Border & Core \\
\hline 0 & 50.3 & 27.5 & 31.2 & 57.4 & 32.0 & 62.4 \\
\hline 1 & 30.9 & 38.3 & 39.5 & 30.8 & 39.6 & 21.9 \\
\hline 2 & 12.3 & 21.2 & 17.7 & 8.6 & 18.0 & 9.6 \\
\hline 3 & 5.5 & 11.4 & 9.9 & 2.5 & 5.8 & 4.1 \\
\hline 4 & 1.1 & 1.6 & 1.6 & 0.7 & 4.6 & 2.0 \\
\hline
\end{tabular}


fore the rates of abandonment are low, with the lowest share of the FLA3 \& FLA4 classes, equal to $3.2 \%$ (Table 3 ).

These preliminary results suggest that each of the seven landscape parks to be studied may display a specific pattern of farmland abandonment, depending on local environmental conditions, forest area and density of settlement.

\section{Expected results}

We have only started to explore the questions, therefore instead of tentative answers, formulating of expected results would be more plausible at this stage of our project. We expect that (i) spatial distribution of abandoned farmland in central Poland is related to biophysical features of the study area and coincides with poor topographic and edaphic conditions for modern agriculture, (ii) species structures of plant and macro-fungi of abandoned farmland depend on the site abiotic conditions and age of habitat, (iii) abandoned farmlands with similar abiotic conditions have similar plant and macro-fungi communities, (iv) plant and macro-fungi of abandoned farmland form communities on a small scale

We hypothesise that geographical distribution of farmland abandonment is related to the existing protected areas, in particular to landscape parks, and we further expect that decreased intensity of human activity in the surrounding of protected areas affects the ecological processes within them. A theoretical foundation of this prediction is based on the ecological mechanisms by which land use outside protected areas alters ecology and biodiversity within reserves (Hansen, DeFries, 2007). These include the change in effective size of ecosystem in which reserve is located, change in energy and material flows into and out of reserve, formation of crucial habitats and diminishing the exposure to human impact at park edges.

Overall, we aim to evaluate ecological potential of abandoned farmland in landscape scale.

\section{Future work and potential}

Analyses of the data acquired in the first season of field work will continue with an emphasis on vegetation-environment relationships in the detailed study sites and the assessment of suitability of the abandoned lands to strengthen the ecological landscape structure and supplement the existing network of protected areas.

Our research could be a point of departure for studies on the suitability of abandoned land ecosystems for invertebrates and vertebrates, for further studies on the trajectories of abandoned farmland use and vegetation change, and their potential for the enhancement of ecological connectivity. The project is expected to contribute to the research on balancing rural land uses to improve performance of ecosystem services.

\section{Acknowledgements}

I gratefully acknowledge the support for this research by the Polish National Science Centre (Narodowe Centrum Nauki): grant N N305 176040. 


\section{References}

DLG (2005). Land Abandonment, Biodiversity, and the CAP. Land Abandonment and Biodiversity in Relation to the $1^{\text {st }}$ and $2^{\text {nd }}$ Pillars of the EU's Common Agricultural Policy; Outcome of an International Seminar in Sigulda, Latvia, 7-8 October, 2004. Utrecht: Government Service for Land and Water Management of the Netherlands (DLG).

Faliński, J.B. (1986). Sukcesja roślinności na nieużytkach porolnych jako przejaw dynamiki ekosystemu wyzwolonego spod długotrwałej presji antropogenicznej. Wiadomości Botaniczne, 30, 25-50.

GUS (2004). Notatka dotycząca publikacji „Charakterystyka rolniczej przestrzeni produkcyjnej Polski”.http://www. stat.gov.pl/cps/rde/xbcr/gus/PUBL_notatka_dot_charakterystyka_rolniczej_przestrzeni_produkcyjnej_polski. pdf. Accessed 12th Sept 2012.

GUS (2011). Użytkowane gruntów. Powszechny spis rolny 2010. http://www.stat.gov.pl/cps/rde/xbcr/gus/rl psr2010_raport_uzytkowanie_gruntow.pdf, Accessed: 10th Sept 2012.

GUS (2011a). Rocznik statystyczny Rzeczypospolitej Polskiej 2011. http://www.stat.gov.pl/cps/rde/xbcr/gus/rs_rocznik_statystyczny_rp_2011.pdf, Accessed 10th Sept 2012.

Hansen, A.J. \& DeFries R. (2007). Ecological mechanisms linking protected areas to surrounding lands. Ecol. Appl., 17(4), 974-988. DOI: 10.1890/05-1098.

Harasimiuk, A. (2008). Soils and chemical cycling of elements after land use changes (case studies). Miscellanea Geographica, 13, 145-151.

Höchtl, F., Lehringer, S. \& Konold W. (2005). "Wilderness": what it means when it becomes a reality - a case study from the southwestern Alps. Landsc. Urban Plann., 70, 85-95. DOI:10.1016/j.landurbplan.2003.10.006.

Keenleyside, C. \& Tucker G.M. (2010). Farmland Abandonment in the EU: an Assessment of Trends and Prospects. Report prepared for WWF. London: Institute for European Environmental Policy.

Park Krajobrazowy Wzniesień Łódzkich (2003). Załącznik nr 1 do rozporządzenia nr 5/03 Wojewody Łódzkiego z dnia 31 lipca 2003. Synteza planu ochrony. http://www.pkwl.pl/cms/zalaczone_pliki/zal_1.pdf, Accessed 28th October 2012.

Pointereau, P., Coulon, F., Girard, P., Lambotte, M., Stuczynski, T., Sanchez Ortega, V., Del Rio, A., Anguiano, E., Bamps, C. \& Terres J.-M. (2008) (Eds). Analysis of Farmland Abandonment and the Extent and Location of Agricultural Areas that are Actually Abandoned or are in Risk to be Abandoned. Institute for Environment and Sustainability, Joint Research Centre, EC.

Poláková, J., Tucker, G., Hart, K., Dwyer, J. \& Rayment M. (2011). Addressing biodiversity and habitat preservation through measures applied under the Common Agricultural Policy. Report Prepared for DG Agriculture and Rural Development, Contract No. 30-CE-0388497/00-44. London: Institute for European Environmental Policy.

Rey Benayas, J.M., Martins, A., Nicolau, J.M. \& Schulz J. (2007). Abandonment of agricultural land: an overview of drivers and consequences. Perspectives in Agriculture, Veterinary Science, Nutrition and Natural Resources, 2(057), 1-14, DOI: 10.1079/PAVSNNR20072057.

Strijker, D. (2005). Marginal lands in Europe - causes of decline. Basic and Applied Ecology, 6, 99-106. DOI: 10.1016/j.baae.2005.01.001.

US w Łodzi (2012). Rocznik statystyczny województwa łódzkiego 2012.http://www.stat.gov.pl/cps/rde/xbcr/lodz/ ASSETS_RocznikLodzkie2012.pdf, Accessed 29th Nov 2013. 